\title{
Design, Synthesis and Biological Evaluation of 1-Phenyl-Ethanone Derivatives for Multi-Targeted Treatment of Alzheimer's Disease
}

Meihao Liang ${ }^{1 \#}$, Wenhai Huang ${ }^{1,2 \#}$, Beibei Wang ${ }^{1}$, Wenhua Wei ${ }^{3}$, Chixiao Zhang ${ }^{1}$, Zhimin Zhang ${ }^{1}$ and Zhengrong Shen ${ }^{1 *}$

${ }^{1}$ Institute of Materia Medica, Zhejiang Academy of Medical Sciences, Hangzhou, PR China

${ }^{2}$ State Key Laboratory of Medicinal Chemical Biology, NanKai University, Tianjin, PR China

${ }^{3}$ Southern University of Science and Technology, Shenzhen, PR China

\#These authors contributed equally to this work

\begin{abstract}
Alzheimer's disease (AD) is a progressive neurodegenerative disease leading to the irreversible loss of brain neurons and cognitive abilities. Multiple factors, such as acetylcholinesterase (AChE), metal ions and amyloid- $\beta$ (A $\beta$ ) have been considered play an important role in the pathogenesis of AD. In this work, AChE and metal ions, both of which are also associated with the deposition of $A \beta$ in the brain, were selected as targets simultaneously. 22 compounds were rationally designed by hybridizing $\mathrm{AChE}$ inhibitor rivastigmine and metal chelator 2-hydroxyacetophenone, in a hoping that these compounds could be as a substrate and inhibitor of AChE, while the subsequent enzymatic hydrolysis products by AChE could be as a metal ion chelator. Thus these 22 compounds were synthesized and their biological activities against $A D$ were evaluated in vitro. The results showed that compound w8 presented the best inhibitory activity of $A C h E\left(\mathrm{IC}_{50}=31.9 \mu \mathrm{M}\right)$, and the representing enzymatic hydrolysis products $7 \mathrm{f}$ exhibted the metal chelating function. Furthermore, both $\mathbf{7 f}$ and one of the targeted compound w15 could inhibit the aggregation of $A \beta$.
\end{abstract}

Keywords: Alzheimer's disease; Amyloid- $\beta$; AChE inhibitor; Metal chelators; Drug design

\section{Introduction}

Alzheimer's disease (AD), the leading cause of dementia in the elderly, is a complex neurodegenerative disorder [1,2]. Since multiple factors, such as reduced acetylcholine (ACh) level, metal dyshomeostasis, oxidative stress and amyloid- $\beta(A \beta)$ aggregation, have been considered to play important roles in the pathogenesis of $\mathrm{AD}$, it is difficult to shed desirable therapeutic effect for single-target strategy [3,4]. Thus, MultiTarget-Directed Ligand, which is rationally designed to hit multiple targets for a particular disease to improve pharmacological profiles, raise as a potentially more effective strategy for AD treatment [5-7].

Until now, clinical available drugs approved for $\mathrm{AD}$ are mainly AChE inhibitors $[8,9]$, which improve the ACh level, one of the important neurotransmitters responsible for cognition in the central cholinergic system. Some experiments also find that the level of metal ions in $\mathrm{AD}$ patients are 3-7 folds higher than that of healthy individuals [10], it indicated that the dyshomeostasis of biometals $(\mathrm{Fe}, \mathrm{Cu}, \mathrm{Zn})$ in the brain may contribute to AD pathology [11]. Clioquinol (a classic metal chelator used as antifungal drug and antiprotozoal drug), had been tested to treat $\mathrm{AD}[12,13]$. The phase II clinical trials suggested that clioquinol could halt cognitive decline in $\mathrm{AD}$, possibly owing to its ability to chelate copper and zinc ions. Therefore, decreasing the level of metal ions in brain by using metal chelator represents another rational therapeutic approach for the treating of $\mathrm{AD}$.

Furthermore, both $\mathrm{AChE}$ and metal ions are associated with $\mathrm{A} \beta$, which plays a central role in the pathogenesis of $\mathrm{AD}$ [14-18]. Recent evidence indicated certain links between $A \beta$ and AChE [19]. AChE could form a complex with $A \beta$, which changes the conformation of $A \beta$ and then promotes the aggregation $A \beta[20,21]$. While metal ions binding to soluble $A \beta$ via histidine residues could greatly accelerate $A \beta$ nucleated aggregation [22,23], which is enhanced under mild acidic conditions similar to that present in aging and $\mathrm{AD}$ brains. Thus, simultaneously inhibition of AChE and chelation of metal ions, both of which also contribute to the same result of decelerating the $A \beta$ aggregation with different mechanisms, may form synergistic effect in the treatment of $\mathrm{AD}[24]$.

Considering the above, we focused on multi-target-directed ligands integrated AChE inhibitors and metal chelators, which not only reduce the hydrolysis of ACh and decrease the levels of metal ions in brain but also slow down the aggregation of $A \beta$. Rivastigmine, an AChE inhibitor approved for the treatment of $\mathrm{AD}$, could be cleavaged by $\mathrm{AChE}$ to release metabolites NAP226-90 in brain (Figure 1) [25], which inspired us to design a molecular skeleton that could be as a substrate and inhibitor of AChE first, and then the subsequent hydrolysis products by AChE could be as a metal ion chelator. Based on this design strategy, 1-phenyl-ethanone derivatives were designed by hybridizing AChE inhibitor rivastigmine and metal chelator 2-hydroxyacetophenone (Figure 2). The 1-phenyl-ethanone derivatives were expected to have multifunctional with effects inhibiting $\mathrm{AChE}$ and chelating metal ion, furthermore to have the synergy functions on the inhibition of $A \beta$ formation.

According to the classical drug design methods such as the principle of bioisosteres and scaffold hopping, a series of 1-phenyl-ethanone derivatives had been designed by changing group $R_{1}, R_{2}$ and $R_{3}$. After screening by the Rule of Five, 22 compounds were picked up (Figure 2 ) and then predicted the blood brain barrier (BBB) permeability by Discovery Studio 2.1. The results showed that all the compounds had good permeability through the BBB (Figure 3). Therefore, a series of 1-phenyl-ethanone derivatives were synthesized and their biological activities against $\mathrm{AD}$ were evaluated in vitro.

\section{Results and Discussion}

\section{Chemistry}

With hydroxyl acetophenone $\mathbf{1}$ as starting material, the carbonyl was reduced by sodium borohydride first to form 2 , and then 2

*Corresponding author: Zhengrong Shen, Institute of Materia Medica, Zhejiang Academy of Medical Sciences, Hangzhou, PR China, Tel: +086057188215506 E-mail: shenzr@zjams.com.cn

Received Septemper 28,2017; Accepted October 10,2017; Published October 27,2017

Citation: Liang M, Huang W, Wang B, Wei W, Zhang C, et al. (2017) Design Synthesis and Biological Evaluation of 1-Phenyl-Ethanone Derivatives for Multi-Targeted Treatment of Alzheimer's Disease. Med Chem 7: 285-293. doi: 10.4172/2161-0444.1000469

Copyright: ( 2017 Liang M, et al. This is an open-access article distributed under the terms of the Creative Commons Attribution License, which permits unrestricted use, distribution, and reproduction in any medium, provided the original author and source are credited. 


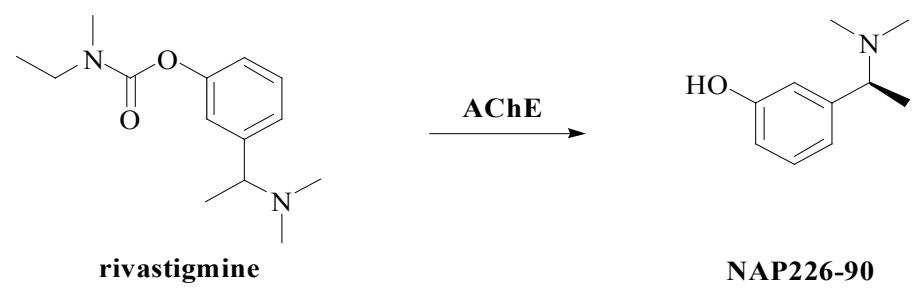

Figure 1: The enzymatic hydrolysis of Rivastigmine by AChE.

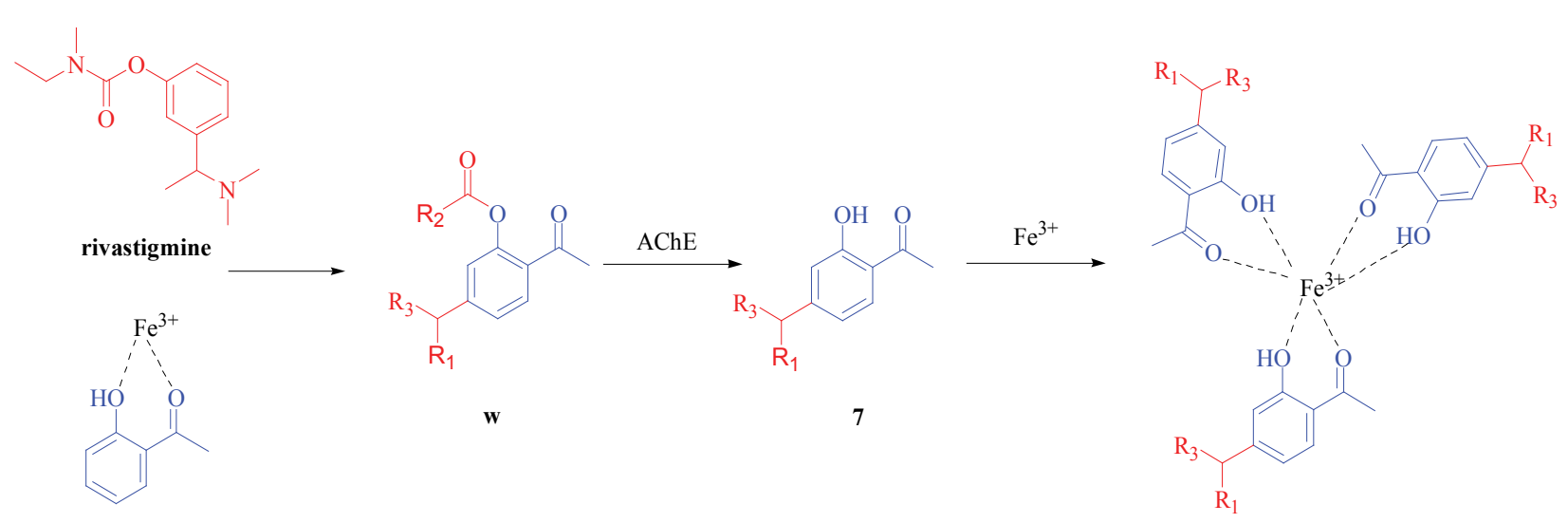

2- hydroxyacetophenone
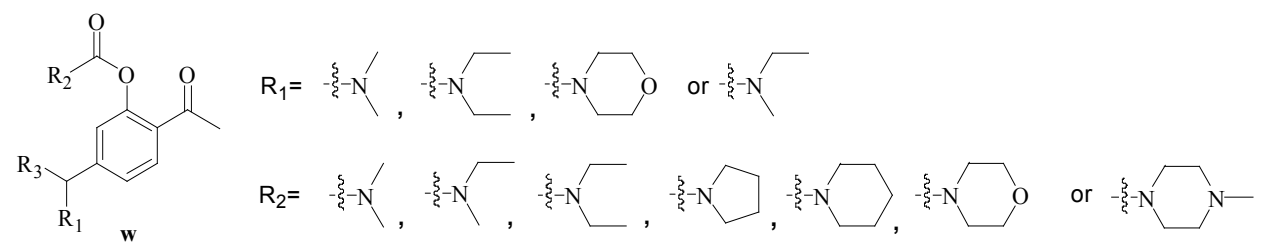

$\mathrm{R}_{3}=-\xi \mathrm{CH}_{3}$

Figure 2: The design and functions of targeted molecular skeleton.

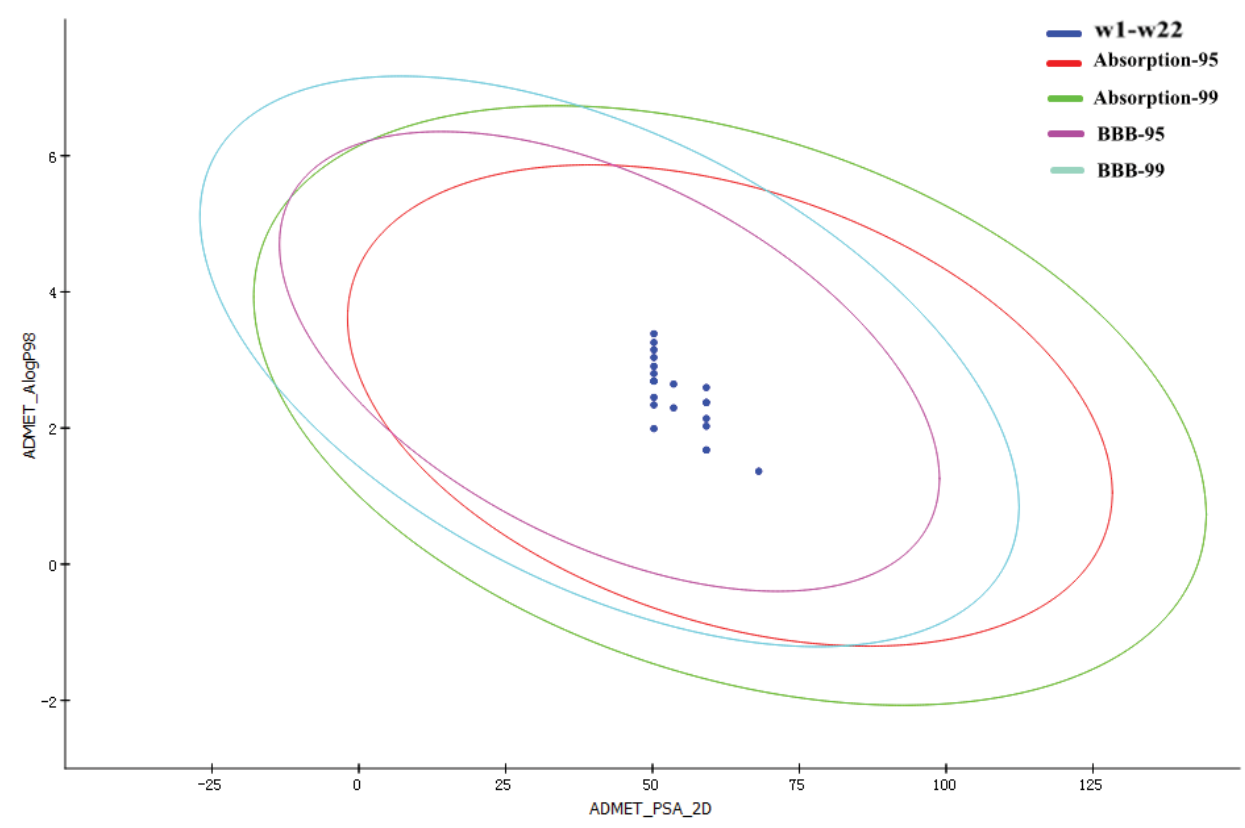

Figure 3: The prediction of BBB permeability of designed compounds. 
was acetylated into 3 with acetic anhydride for the protection of phenolic hydroxyl. By chlorination of 3 with thionyl chloride and further condensation of $\mathbf{4}$ with different secondary amines, a series of compounds $\mathbf{5}$ were obtained. After acetylation of $\mathbf{5}$, the produced critical intermediates 6 through the Fries Rearrangement enabled the preparation of 7. Finally, the targeted compounds $\mathbf{w 1} \sim \mathbf{w 2 2}$ were synthesized by esterification of 7 with different carbamyl chlorides. The synthetic route was shown in Figure 4.

Reagents and condition: a. $\mathrm{NaBH}_{4}$, THF, $25^{\circ} \mathrm{C}, 3 \mathrm{~h}$; b. $\mathrm{KOH}, 0^{\circ} \mathrm{C}$, 2 h; c. DMF, $\mathrm{SOCl}_{2}, \mathrm{DCM}, 25^{\circ} \mathrm{C}, 2 \mathrm{~h}$; d. KI, $\mathrm{R}_{1}$, acetonitrile, reflux; e. $\mathrm{Na}_{2} \mathrm{CO}_{3}, \mathrm{DCM}, 0^{\circ} \mathrm{C}$; $\mathrm{f} . \mathrm{AlCl}_{3}$, nitrobenzene, $150^{\circ} \mathrm{C}, 5 \mathrm{~h}$; g. DMAP, TEA, THF, reflux, $4 \mathrm{~h}$.

\section{In vitro biological evaluation}

Metal chelating effect: The increase levels of iron, zinc and particularly copper on brain was reported to actively contribute to the formation of amyloid plaques by generating more reactive oxygen species through the $A \beta$ (1-42) metal complex [26]. We once published a review concerning the drug-like metal chelating agents [27]. Many drug-like metal chelating agents were found to be able to reverse $A \beta$ aggregation, dissolve amyloid plaques, and delay the $\mathrm{AD}$-related cognitive impairment. In this presented work, compounds 7 were designed as active ingredients for metal chelating, so that randomly, compound $\mathbf{7 f}$ was picked to test the metal-chelating effect.

The metal-chelating effect of compound $7 \mathbf{f}$ was studied by ultra violet (UV) spectrometry with wavelength ranging from 200 to 400 $\mathrm{nm} .{ }^{27}$ Upon the addition of $\mathrm{Cu}^{2+}, \mathrm{Fe}^{2+}$ and $\mathrm{Zn}^{2+}$ to the $7 \mathrm{f}$ methanol solution, the maximum absorption wavelength or absorption intensity happened to change, representing the formation of $\mathbf{7 f}-\mathrm{Cu}^{2+}, \mathbf{7 f}-\mathrm{Fe}^{2+}$ and $7 \mathbf{f}-\mathrm{Zn}^{2+}$ (Figure 5). In detail, when $\mathrm{Zn}^{2+}$ was added into the solution 7f, the UV absorption intensity was no obvious changing, only the maximum absorption wavelength shifted slightly. When $\mathrm{Fe}^{2+}$ and $\mathrm{Zn}^{2+}$ were added into solution $7 \mathbf{f}$ respectively, the maximum absorption wavelength had no obvious change, while the UV absorption intensity increased obviously. This data revealed that metal-chelating form of $\mathbf{7 f}$ $\mathrm{Cu}^{2+}$ was different from $\mathbf{7 f}-\mathrm{Fe}^{2+}$ and $\mathbf{7} \mathbf{f}-\mathrm{Zn}^{2+}$.

$A \beta$ aggregation inhibition: Compounds $7 \mathbf{f}$ and $\mathbf{w 1 5}$ were tested for their ability to inhibit self-induced $A \beta$ (1 42) aggregation by thioflavin T-based fluorometric assay, [28] with curcumin (Cur) as reference compounds. The fluorescence intensities of five tested groups, respectively $\mathbf{7 f}$, w15, $A \beta$ itself, Cur, and blank, were recorded in Table 1. The morphology of $A \beta(1 \sim 42)$ aggregation was transferred for imaging by transmission electron microscopy with $2 \mu \mathrm{m}$ and 0.5 $\mu \mathrm{m}$ (Figure 6). The fluorescence intensities of w15 was stronger than $\mathbf{7 f}$ hydrolyzed from w15 by AChE, but slightly weaker than the positive the control compound Cur. The results revealed that compounds w15 and $\mathbf{7 f}$ had considerable potencies inhibiting $A \beta$ aggregation.

AChE enzymatic hydrolysis: For confirming that the synthesized compound $\mathbf{w 1} \sim \mathbf{w} 22$ could be hydrolyzed to 7 by AChE, the enzymatic hydrolysis of compound w13 by AChE was investigated in vitro, the hydrolysis products after $0.1 \mathrm{~h}, 0.5 \mathrm{~h}, 1 \mathrm{~h}, 3 \mathrm{~h}, 6 \mathrm{~h}$ was detected respectively by HPLC with w13 and $\mathbf{7 f}$ as external standard (Figure 7). The results indicated that w13 could be hydrolyzed to $7 \mathbf{f}$ by AChE, moreover the hydrolysis was intensified with the increasing of hydrolysis time.

AChE inhibitory activity: The AChE inhibitory activity of 1-phenyethanone derivatives $\mathbf{w 1} \sim \mathbf{w} \mathbf{2 2}$ were tested by spectrophotometric method [29], using rivastigmine as the reference. The percentages of AChE inhibition and $\mathrm{IC}_{50}$ values of all tested compounds were summarized in Table 2.

As shown in Table 1, compounds w1, w8, w10, w22, exhibited moderate AChE inhibitory activities in comparison with rivastigmine, wherein compound w8 displayed most potentially with an $\mathrm{IC}_{50}$ value of $31.9 \mu \mathrm{M}$. Unexpectedly, except the above four compounds, all the rest compounds displayed poor AChE inhibitory activities in this test. It may be attributed to that $\mathbf{w 1} \sim \mathbf{w} \mathbf{2 2}$ are harder to across the narrow aromatic gorge which linked the central site and peripheral site in AChE.[30]. According to results, it was supposed that when $R_{1}$ and $\mathrm{R}_{2}$ were short or small secondary amines, such as $\mathrm{N}$-dimethylamine, N-ethylmethylamine or pyrrolidine, the targeted compounds exhibited better AChE inhibitory activities.

Molecular docking study: In an attempt to understand the molecular interaction between w8 and AChE, a molecular docking study was built on previous work,[31] which was performed by Discovery Studio 4.0/CDOCKER protocol using the crystal structure of E2020/AChE complex (PDB ID: 1EVE) as the template. Docking and

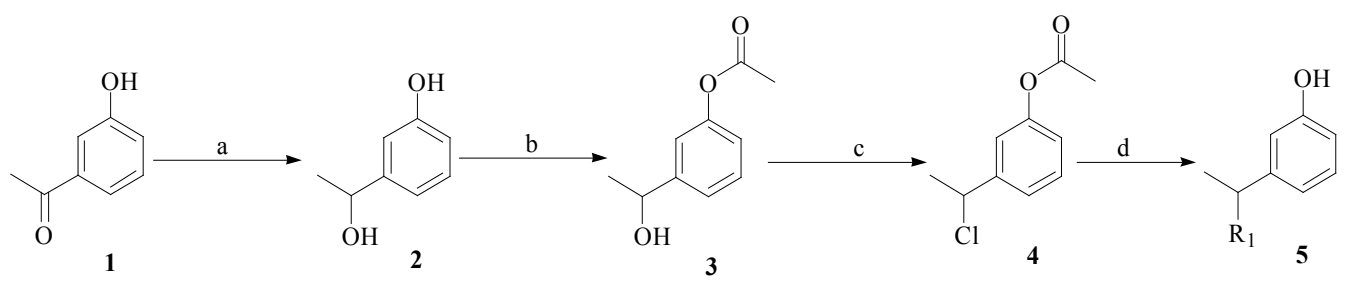<smiles>CC(=O)Oc1cccc(C(C)Br)c1</smiles>
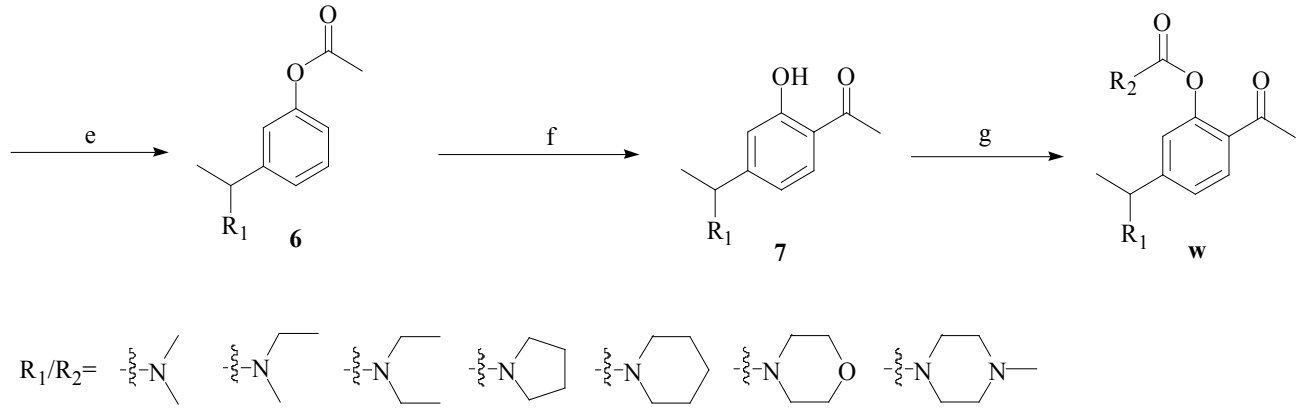

Figure 4: The synthetic route of $\mathbf{w} 1 \sim \mathbf{w} 22$. 
<smiles>CC(=O)c1ccc(C(C)N2CCOCC2)cc1O</smiles>
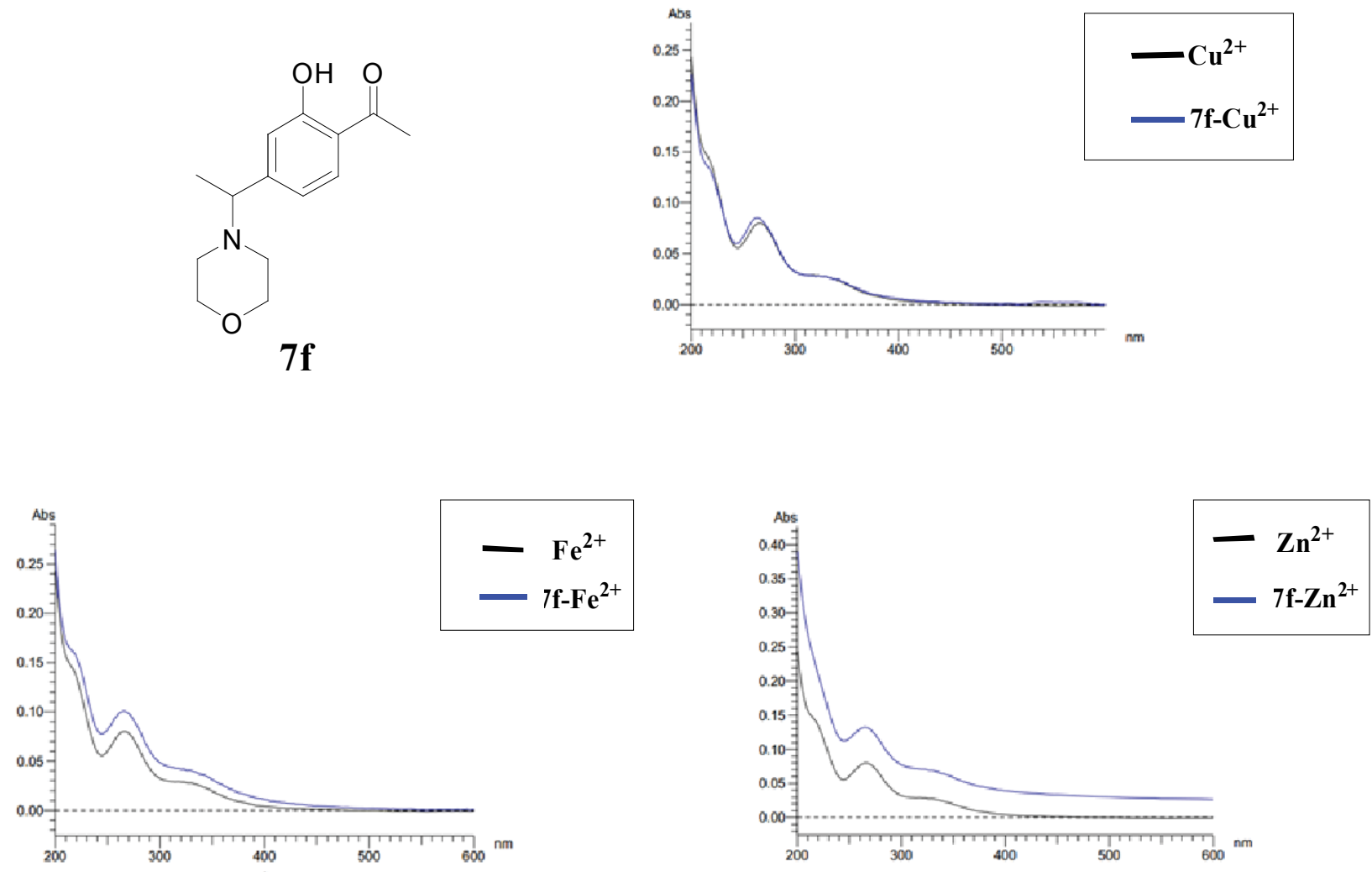

Figure 5: The absorption spectra of $7 f(25 \mu \mathrm{M})$ chelate Copper, Iron and Zinc ions.

\begin{tabular}{|l|l|l|l|l|l|}
\hline & $\mathbf{1}$ & $\mathbf{2}$ & $\mathbf{3}$ & Average & Absolute \\
\hline Blank & 24958 & 24928 & 24772 & 24886 & Inhibition\% \\
\hline A $\boldsymbol{\beta}$ itself & 31044 & 33188 & 35388 & 33206.67 & 8320.67 \\
\hline Cur & 29563 & 28837 & 28692 & 29030.67 & 4144.67 \\
\hline $\mathbf{7 f}$ & 31202 & 31228 & 29030 & 30486.67 & 5600.67 \\
\hline w15 & 32061 & 29730 & 28208 & 29999.67 & 50.19 \\
\hline
\end{tabular}

Table 1: The results of the ability to inhibit self-induced $A \beta$ aggregation.

subsequent scoring studies were performed using default parameters. It was disclosed that the binding pattern of $\mathbf{w 8}$ into the AChE was similar to the crystal structure of rivastigmine/AChE (PDB ID:1GQR). As shown in Figure 8, hydrogen bond interactions were observed between amide group and Gly118/Ser200 with distance of $2.15 \AA$ and 1.83 $\AA$, respectively. Besides, the charged nitrogen also made a hydrogen bond interaction with Tyr121 with a distance of $2.68 \AA$. In addition, the benzene ring formed $\pi-\pi$ stacking with Trp334. Moreover, same as the binding pattern of rivastigmine, the carbamate group of $\mathbf{w 8}$ was very close to the esteratic site (Ser200, Glu327 and His440), which was beneficial to the enzymatic hydrolysis of carbamate group, and then resulted in a 'flattening' of the carbamate moiety over the esteratic site, producing the prolonged inhibition of AChE.

\section{Conclusion}

In summary, a series of 1-phenyl-ethanone derivatives have been successfully designed, synthesized and their biological activities were evaluated in respect to metal chelating, AChE inhibiting and $A \beta$ aggregation inhibiting for the treatment of AD. Among which, several targeted compounds exhibited AChE inhibiting acitivity, although it was somewhat decreased compared with ravastigmine. It was also proved that 1-phenyl-ethanone derivatives could be hydrolyzed by $\mathrm{AChE}$ to release $\mathrm{OH}-$ metabolite chelating $\mathrm{Cu}^{2+}, \mathrm{Fe}^{2+}$ and $\mathrm{Zn}^{2+}$. Meanwhile the tested 1-phenyl-ethanone derivative and its hydrolysis product showed the ability to inhibit the $A \beta$ aggregation. These results validated the possibility of our molecular design strategy, while improvement of $\mathrm{AChE}$ activities of 1-phenyl-ethanone derivatives would be the important point in the next stage of the anti-AD drug development with multi-targeted strategy.

\section{Experimental Section}

\section{Chemical synthesis}

All solvents used were analytical grade. Melting points were recorded on a Buchi apparatus without correction, IR spectra were recorded on a Bruker VECTOR 22 FTIR spectrophotometer. ${ }^{1} \mathrm{H}$ NMR spectra were recorded on a Bruker Avance III 500M instrument (chemical shifts are expressed as $\delta$ values relative to TMS as internal standard). Mass spectra (MS) were recorded on an Esquire-LC-00075 spectrometer.

3-(1-hydroxy-ethyl)-phenol (2): A solution of $150 \mathrm{~g}$ compound 1 in $500 \mathrm{~mL}$ THF was cooled to $0^{\circ} \mathrm{C}$ with a salt-ice bath and sodium borohydride $(51.0 \mathrm{~g}, 1.3 \mathrm{~mol})$ was added in batches. After that, the reaction was stirred at room temperature for $3 \mathrm{~h}$, and then was quenched 

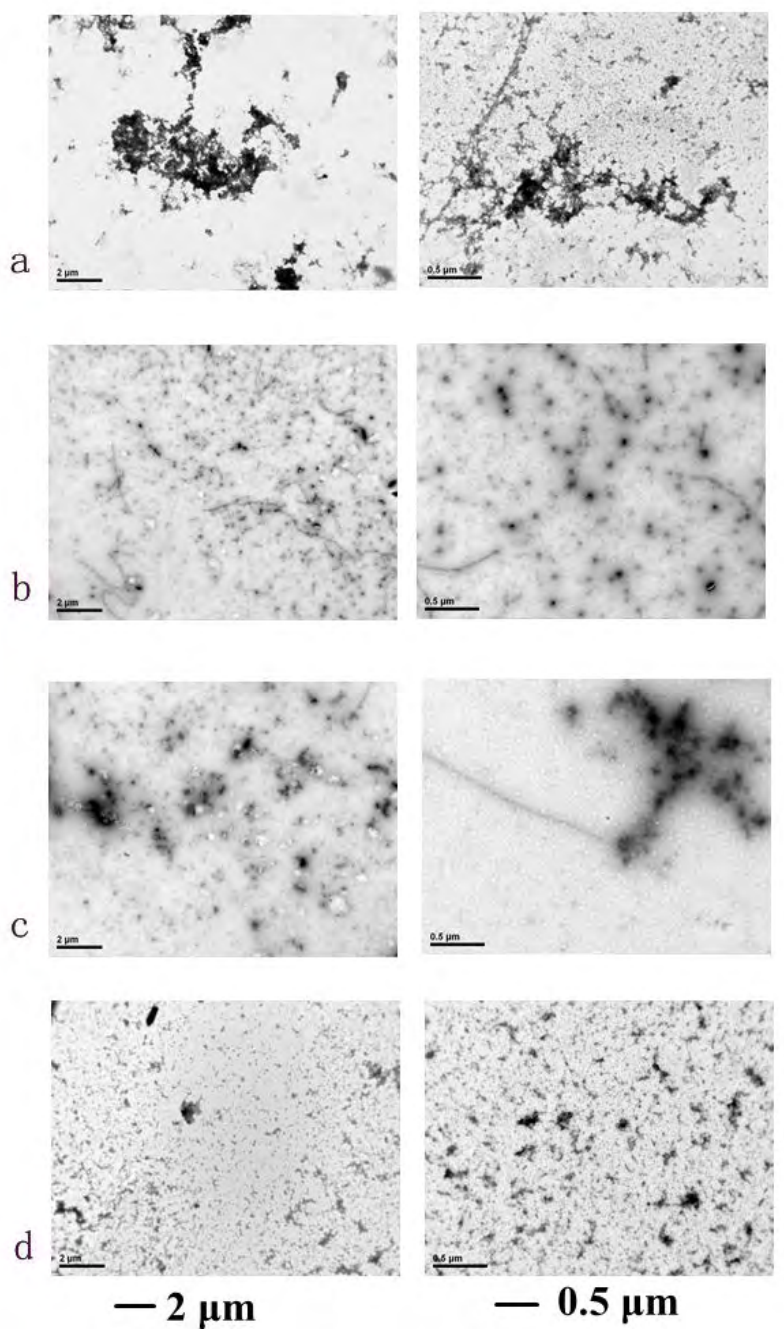

Figure 6: Transmission electron micrographys of $A \beta$ aggregation inhibition a. $A \beta(25 \mu \mathrm{M})$ diluted with $10 \mathrm{mM}$ phosphate buffer. b. $\mathrm{A} \beta(25 \mu \mathrm{M})$ mixed with Cur $(20 \mu \mathrm{M})$ in $1 \%$ final DMSO concentration. c. Compound $\mathbf{7 f}$ mixed with $A \beta(25 \mu \mathrm{M})$ in $1 \%$ final DMSO concentration. d. w15 mixed with $A \beta(25$ $\mu \mathrm{M})$ in $1 \%$ final DMSO concentration.

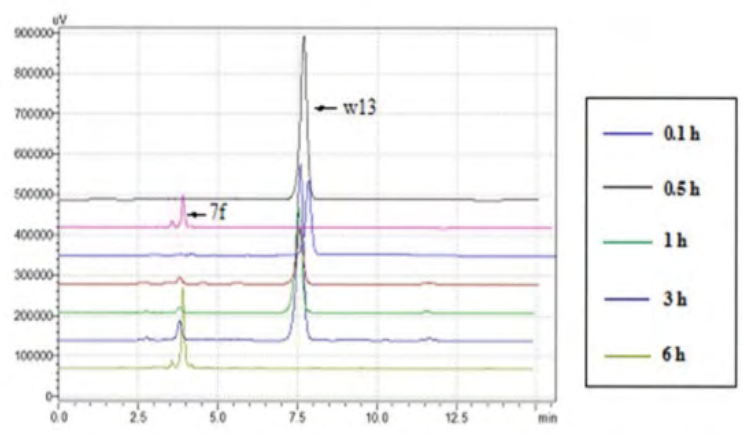

Figure 7: The HPLC profiles of w13 and 7f in the hydrolysis with AChE.

with water. The aqueous solution was adjusted $\mathrm{pH}$ to $5 \sim 6$ and extracted with ethyl acetate. The organic layer was dried over $\mathrm{Na}_{2} \mathrm{SO}_{4}$, and the residue was crystallized with ethyl acetate to give 2 (132.6 g, $72.5 \%)$. 3-(1-hydroxyl) ethyl benzoic acid ethyl ester (3): Compound 2 $(126.6 \mathrm{~g}, 0.9 \mathrm{~mol})$ was dissolved in potassium hydroxide solution $(5.5$ $\left.\mathrm{mol} \cdot \mathrm{L}^{-1}, 500 \mathrm{~mL}\right)$ and cooled to $0^{\circ} \mathrm{C}$. Acetic anhydride $(113 \mathrm{~mL}, 1.2$ mol) was slowly dripped into the solution with stirring. The mixture was stirred at room temperature for $2 \mathrm{~h}$ and then extracted with ethyl acetate. The organic layer was successively washed with saturated sodium bicarbonate, saturated sodium chloride, water and dried over $\mathrm{Na}_{2} \mathrm{SO}_{4}$, at last ethyl acetate was removed to give 3 (125.5 g, 76.3\%).

3-(1-chlorine) ethyl benzoic acid ethyl ester (4): Compound 3 (125.5 g, $0.7 \mathrm{~mol})$ was dissolved in the solution of distilled DCM (500 $\mathrm{mL}$ ) and DMF (123 mL, $1.6 \mathrm{~mol}$ ). Purified $\mathrm{SOCl}_{2}$ was added slowly into the solution $(67 \mathrm{~mL}, 1.1 \mathrm{~mol})$ and the reaction was stirred at room temperature for $2 \mathrm{~h}$. Then the mixture was slowly added into crushed ice, adjusted $\mathrm{pH}$ to $7 \sim 8$. The organic layer was separated, and the aqueous layer was extracted three times with chloroform. The combined organic layer was washed with water and dried over $\mathrm{Na}_{2} \mathrm{SO}_{4}$. The organic solvent was evaporated, and then the residue was chromatographed on silica gel using petroleum ether to give compound 4 (127.0 g, 91.4\%).

General procedure A for the syntheses of compounds $(5 \mathrm{a} \sim 5 \mathrm{~g})$ : Taking 5a as an example: Compounds $4(12.0 \mathrm{~g}, 60 \mathrm{mmol}), \mathrm{KI}(80 \mathrm{mmol})$, $\mathrm{K}_{2} \mathrm{CO}_{3}$ in acetonitrile $(200 \mathrm{~mL})$, and $\mathrm{N}$-dimethylamine hydrochloride (200 mmol) were mixed together, the mixture was stirred at $45^{\circ} \mathrm{C}$ for $24 \mathrm{~h}$. The solvent was removed, then the residues were dissolved in water and the solution was acidified to $\mathrm{pH} 4 \sim 5$. The aqueous solution was washed three times with ethyl acetate and adjusted to $\mathrm{pH} 8$, then extracted with ethyl acetate. After removal of ethyl acetate, compound 5a $(4.0 \mathrm{~g}, 40.1 \%)$ was obtained.

General procedure $B$ for the synthesis of compounds $(6 \mathrm{a} \sim 6 \mathrm{~g})$ : Taking $\mathbf{6} \mathbf{a}$ as an example: $\mathbf{5 a}(3.8 \mathrm{~g}, 23.0 \mathrm{mmol})$ and sodium carbonate $(1.5 \mathrm{~g}, 14.0 \mathrm{mmol})$ were dissolved in DCM. Then acetic anhydride $\left(2.6 \mathrm{~mL}, 28 \mathrm{mmol}\right.$ ) was added slowly in the above mixture at $0^{\circ} \mathrm{C}$. The reaction mixture was stirred at room temperature and monitored by TLC. When the reaction was completed, dichloromethane was removed under vacuum. The solution of the residue was dissolved in water, acidified to $\mathrm{pH} 4 \sim 5$ and stirred for another $0.5 \mathrm{~h}$. Followed by the aqueous solution was washed with ethyl acetate, adjusted to $\mathrm{pH} 8$ with $\mathrm{Na}_{2} \mathrm{CO}_{3}$, and then extracted with ethyl acetate, dried over $\mathrm{Na}_{2} \mathrm{SO}_{4}$, at last ethyl acetate was removed to give to give compound $\mathbf{6 a}(4.3 \mathrm{~g}$, 90.2\%).

General procedure $C$ for the synthesis of compounds $(7 \mathbf{a} \sim 7 \mathrm{~g})$ : Taking $7 \mathbf{a}$ as an example: $\mathbf{6 a}(3.9 \mathrm{~g}, 19.0 \mathrm{mmol})$ and aluminium trichloride (12.6 g, $95.0 \mathrm{mmol})$ were dissolved in nitrobenzene $(20$ $\mathrm{mL})$. Acetic anhydride was dissolved in nitrobenzene $(20 \mathrm{~mL})$ also, and added dropwise to the above reaction, stirred for $0.5 \mathrm{~h}$ at $150^{\circ} \mathrm{C}$. Then the solution of $\mathrm{Na}_{2} \mathrm{CO}_{3}$ was added in slowly to adjust $\mathrm{pH}$ to 8 . The aqueous solution was extracted with ethyl acetate, after dried over $\mathrm{Na}_{2} \mathrm{SO}_{4}$, ethyl acetate was removed to give compound $7 \mathbf{a}(2.3 \mathrm{~g}, 58.1 \%)$.

General procedure $D$ for the syntheses of compounds (w1 w22): Taking w1 as an example: The compounds $7 \mathbf{a}(13 \mathrm{mmol})$, DMAP (160.0 mg, $1.3 \mathrm{mmol}$ ), dimethylcarbamoyl chloride and TEA (156 $\mathrm{mmol})$ were dissolved in THF $(100 \mathrm{~mL})$. Then the mixture was stirred at reflux for $2 \mathrm{~h}$. When the reaction was completed, acidified to $\mathrm{pH} 4 \sim 5$ with and washed with ethyl acetate. The aqueous layer was adjusted to pH 9 and extracted with ethyl acetate. After dried over $\mathrm{Na}_{2} \mathrm{SO}_{4}$, ethyl acetate was removed to give compound w1. yield 90.2\%. ${ }^{1} \mathrm{H}$ NMR (400 $\left.\mathrm{MHz}, \mathrm{CDCl}_{3}\right): \delta 7.74(1 \mathrm{H}, \mathrm{d}, J=8.0 \mathrm{~Hz}), 7.23\left(1 \mathrm{H}, \mathrm{dd}, J_{1}=8.0 \mathrm{~Hz}, J_{2}=1.2\right.$ $\mathrm{Hz}), 7.11(1 \mathrm{H}, \mathrm{d}, J=1.2 \mathrm{~Hz}), 3.30(1 \mathrm{H}, \mathrm{q}, J=6.4 \mathrm{~Hz}), 3.15(3 \mathrm{H}, \mathrm{s}), 3.05$ $(3 \mathrm{H}, \mathrm{s}), 2.55(3 \mathrm{H}, \mathrm{s}), 2.22(6 \mathrm{H}, \mathrm{s}), 1.36(3 \mathrm{H}, \mathrm{d}, J=6.4 \mathrm{~Hz}) . \mathrm{MS}\left([\mathrm{M}+\mathrm{H}]^{+}\right)$ $\mathrm{m} / \mathrm{z}$ calcd for $\mathrm{C}_{15} \mathrm{H}_{22} \mathrm{~N}_{2} \mathrm{O}_{3} 279.2$; found 279.2 . 
Citation: Liang M, Huang W, Wang B, Wei W, Zhang C, et al. (2017) Design, Synthesis and Biological Evaluation of 1-Phenyl-Ethanone Derivatives for Multi-Targeted Treatment of Alzheimer's Disease. Med Chem 7: 285-293. doi: 10.4172/2161-0444.1000469

\begin{tabular}{|c|c|c|c|c|}
\hline Compound & $\mathbf{R}_{1}$ & $\mathbf{R}_{2}$ & Inhibition $^{\mathrm{a}}(\%)$ & $\mathrm{IC}_{50}(\boldsymbol{\mu M})$ \\
\hline Rivastigmine & -- & -- & $31.0^{\mathrm{b}}$ & 1.3 \\
\hline w1 & $-\xi-1$ & $-\xi-1$ & 30.3 & 94.3 \\
\hline w2 & $-\frac{\xi}{-3}-1$ & $-\frac{\xi}{-\xi}-1$ & 18.7 & -- \\
\hline w3 & $-\xi-1$ & $-\xi$ & 17.1 & -- \\
\hline w4 & & & 9.8 & -- \\
\hline w5 & $-\frac{\xi}{\xi}-1$ & & 18.5 & -- \\
\hline w6 & & & 14.6 & -- \\
\hline w7 & & $-\xi-$ & 18.0 & -- \\
\hline w8 & & $-\xi$ & 44.9 & 31.9 \\
\hline w9 & & & 11.2 & -- \\
\hline w10 & & & 30.2 & 61.8 \\
\hline w11 & & & 12.7 & -- \\
\hline w12 & & & 6.2 & -- \\
\hline w13 & & $-\xi$ & 9.9 & -- \\
\hline w14 & & -乡- & 6.8 & -- \\
\hline w15 & & & 7.9 & -- \\
\hline w16 & & & 6.9 & -- \\
\hline w17 & & $-\xi$ & 11.9 & -- \\
\hline w18 & & $-\xi_{-}^{\xi}-1$ & 4.4 & -- \\
\hline w19 & $-{ }_{-}^{\xi}-N$ & $-\xi-N$ & 17.4 & -- \\
\hline w20 & & $-\xi-N$ & 21.9 & -- \\
\hline w21 & & $-\xi-\mathrm{N}$ & 14.4 & -- \\
\hline w22 & & $-\underline{-\xi}-N$ & 24.9 & 80.3 \\
\hline
\end{tabular}

Table 2: Inhibition of AChE activity and value of $\mathrm{IC}_{50}$.

a: Inhibition of AChE activity of w1 w22 were measured in $50 \mathrm{mM}$; $\mathbf{b}$ : Inhibition of AChE activity of rivastigmine was measured in $1 \mu \mathrm{M}$
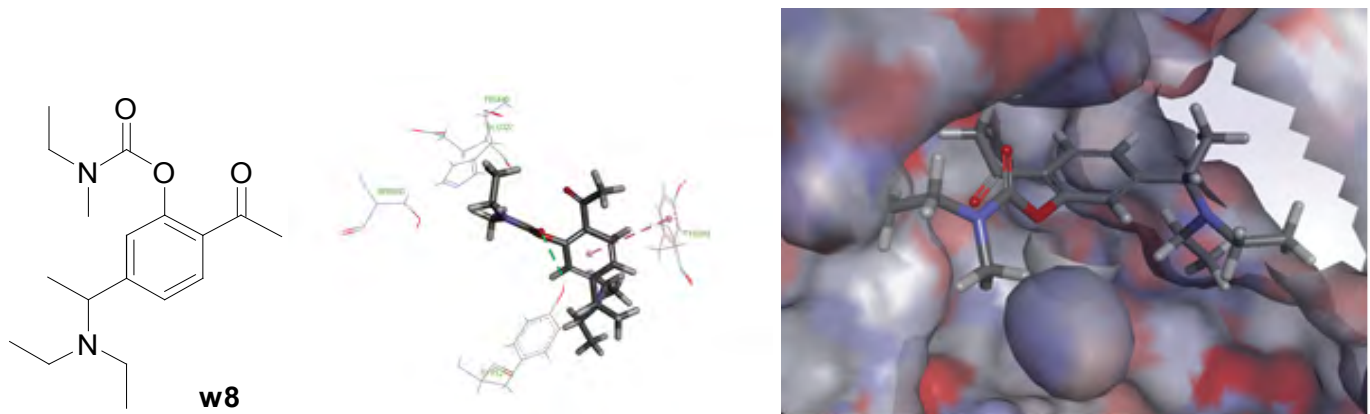

Figure 8: The molecular docking of representative compound w8 with AChE. 
Ethyl-methyl-carbamic acid 2-acetyl-5-(1-dimethylamino-ethyl)phenyl ester (w2): Compound w2 was obtained from compound 7a and N-ethyl-N-methylcarbamoyl chloride by general procedure $\mathrm{D}$; yield 90.2\%. ${ }^{1} \mathrm{H}$ NMR $\left(400 \mathrm{MHz}, \mathrm{CDCl}_{3}\right): \delta 7.65(1 \mathrm{H}, \mathrm{d}, \mathrm{J}=8.0 \mathrm{~Hz}), 7.14$ $(1 \mathrm{H}, \mathrm{d}, \mathrm{J}=8.0 \mathrm{~Hz}), 7.02(1 \mathrm{H}, \mathrm{d}, \mathrm{J}=6.8 \mathrm{~Hz}), 3.45(1 \mathrm{H}, \mathrm{q}, \mathrm{J}=6.8 \mathrm{~Hz}), 3.35$ $(1 \mathrm{H}, \mathrm{q}, \mathrm{J}=6.8 \mathrm{~Hz}), 3.24(1 \mathrm{H}, \mathrm{m}), 3.03(1.5 \mathrm{H}, \mathrm{s}), 2.92(1.5 \mathrm{H}, \mathrm{s}), 2.47(3 \mathrm{H}$, s), $2.14\left(6 \mathrm{H}, \mathrm{s}_{2}\right), 1.29(3 \mathrm{H}, \mathrm{d}, \mathrm{J}=6.0 \mathrm{~Hz}), 1.21(1.5 \mathrm{H}, \mathrm{t}, \mathrm{J}=7.2 \mathrm{~Hz}), 1.12$ $(1.5 \mathrm{H}, \mathrm{t}, \mathrm{J}=7.2 \mathrm{~Hz})$. MS $\left([\mathrm{M}+\mathrm{H}]^{+}\right) \mathrm{m} / \mathrm{z}$ calcd for $\mathrm{C}_{16} \mathrm{H}_{24} \mathrm{NO}_{2} 293.2$; found 293.2.

Diethyl-carbamic acid 2-acetyl-5-(1-dimethylamino-ethyl)phenyl ester (w3): Compound w3 was obtained from compound 7a and diethylcarbamyl chloride by general procedure $\mathrm{D}$; yield $90.4 \% .{ }^{1} \mathrm{H}$ $\operatorname{NMR}\left(400 \mathrm{MHz}, \mathrm{CDCl}_{3}\right): \delta 7.71(1 \mathrm{H}, \mathrm{d}, \mathrm{J}=8.0 \mathrm{~Hz}), 7.21(1 \mathrm{H}, \mathrm{d}, \mathrm{J}=8.0$ $\mathrm{Hz}), 7.09(1 \mathrm{H}, \mathrm{s}), 3.50(2 \mathrm{H}, \mathrm{q}, \mathrm{J}=7.2 \mathrm{~Hz}), 3.38(2 \mathrm{H}, \mathrm{q}, \mathrm{J}=7.2 \mathrm{~Hz}), 3.26$ $(1 \mathrm{H}, \mathrm{q}, \mathrm{J}=6.8 \mathrm{~Hz}), 2.54(3 \mathrm{H}, \mathrm{s}), 2.21(6 \mathrm{H}, \mathrm{s}), 1.35(3 \mathrm{H}, \mathrm{d}, \mathrm{J}=6.8 \mathrm{~Hz}), 1.29$ $(3 \mathrm{H}, \mathrm{t}, \mathrm{J}=7.2 \mathrm{~Hz}), 1.21(3 \mathrm{H}, \mathrm{t}, \mathrm{J}=7.2 \mathrm{~Hz})$. MS $\left([\mathrm{M}+\mathrm{H}]^{+}\right) \mathrm{m} / \mathrm{z}$ calcd for $\mathrm{C}_{17} \mathrm{H}_{26} \mathrm{~N}_{2} \mathrm{O}_{3} 307.2$; found 307.2.

Diethyl-carbamic acid 2-acetyl-5-(1-dimethylamino-ethyl)phenyl ester (w4): Compound w4 was obtained from compound $7 \mathbf{a}$ and 1-pyrrolidinecarbonyl chloride by general procedure $\mathrm{D}$; yield 89.7\%. ${ }^{1} \mathrm{H}$ NMR $\left(400 \mathrm{MHz}, \mathrm{CDCl}_{3}\right): \delta 7.73(1 \mathrm{H}, \mathrm{d}, \mathrm{J}=8.0 \mathrm{~Hz}), 7.22(1 \mathrm{H}$, d, J=8.0 Hz), $7.14(1 \mathrm{H}, \mathrm{s}), 3.62(2 \mathrm{H}, \mathrm{t}, \mathrm{J}=6.8 \mathrm{~Hz}), 3.49(2 \mathrm{H}, \mathrm{t}, \mathrm{J}=6.8 \mathrm{~Hz})$, $3.29(1 \mathrm{H}, \mathrm{q}, \mathrm{J}=6.8 \mathrm{~Hz}), 2.56(3 \mathrm{H}, \mathrm{s}), 2.21(6 \mathrm{H}, \mathrm{s}), 1.98(4 \mathrm{H}, \mathrm{m}), 1.36$ $(3 \mathrm{H}, \mathrm{d}, \mathrm{J}=6.4 \mathrm{~Hz})$. MS $\left([\mathrm{M}+\mathrm{H}]^{+}\right) \mathrm{m} / \mathrm{z}$ calcd for $\mathrm{C}_{17} \mathrm{H}_{24} \mathrm{~N}_{2} \mathrm{O}_{3} 307.2$; found 305.2 .

Piperidine-1-carboxylic acid 2-acetyl-5-(1-dimethylaminoethyl)-phenyl ester (w5): Compound w5 was obtained from compound $7 \mathbf{a}$ and piperidine-1-carbonyl chloride by general procedure $\mathrm{D}$; yield 90.6\%. ${ }^{1} \mathrm{H}$ NMR (400 MHz, $\left.\mathrm{CDCl}_{3}\right): \delta 7.73(1 \mathrm{H}, \mathrm{d}, \mathrm{J}=8.0 \mathrm{~Hz}), 7.22(1 \mathrm{H}$, dd, $\left.J_{1}=8.0 \mathrm{~Hz}, \mathrm{~J}_{2}=1.6 \mathrm{~Hz}\right), 7.10(1 \mathrm{H}, \mathrm{d}, \mathrm{J}=1.6 \mathrm{~Hz}), 3.65(2 \mathrm{H}, \mathrm{m}), 3.52$ $(2 \mathrm{H}, \mathrm{m}), 3.29(1 \mathrm{H}, \mathrm{q}, \mathrm{J}=6.8 \mathrm{~Hz}), 2.55(3 \mathrm{H}, \mathrm{s}), 2.21(6 \mathrm{H}, \mathrm{s}), 1.67(6 \mathrm{H}, \mathrm{m})$, $1.36(3 \mathrm{H}, \mathrm{d}, \mathrm{J}=6.8 \mathrm{~Hz})$. MS $\left([\mathrm{M}+\mathrm{H}]^{+}\right) \mathrm{m} / \mathrm{z}$ calcd for $\mathrm{C}_{18} \mathrm{H}_{26} \mathrm{~N}_{2} \mathrm{O}_{3} 307.2$; found 319.2 .

Synthesis of Morpholine-4-carboxylic acid 2-acetyl-5-(1dimethylamino-ethyl)-phenyl ester (w6): Compound w6 was obtained from compound $7 \mathbf{a}$ and morpholine-4-carbonyl chloride by general procedure D; yield 91.8\%. ${ }^{1} \mathrm{H}$ NMR $\left(400 \mathrm{MHz}, \mathrm{CDCl}_{3}\right): \delta 7.75(1 \mathrm{H}, \mathrm{d}$, $\mathrm{J}=8.0 \mathrm{~Hz}), 7.25\left(1 \mathrm{H}, \mathrm{dd}, \mathrm{J}_{1}=8.0 \mathrm{~Hz}, \mathrm{~J}_{2}=1.2 \mathrm{~Hz}\right), 7.12(1 \mathrm{H}, \mathrm{d}, \mathrm{J}=1.2 \mathrm{~Hz})$, $3.78(5 \mathrm{H}, \mathrm{m}), 3.72(1 \mathrm{H}, \mathrm{m}), 3.56(2 \mathrm{H}, \mathrm{t}, \mathrm{J}=4.4 \mathrm{~Hz}), 3.27(2 \mathrm{H}, \mathrm{t}, \mathrm{J}=4.4$ $\mathrm{Hz}), 2.55(3 \mathrm{H}, \mathrm{s}), 2.21(6 \mathrm{H}, \mathrm{s}), 1.35(3 \mathrm{H}, \mathrm{d}, \mathrm{J}=6.4 \mathrm{~Hz}) . \mathrm{MS}\left([\mathrm{M}+\mathrm{H}]^{+}\right) \mathrm{m} / \mathrm{z}$ calcd for $\mathrm{C}_{17} \mathrm{H}_{24} \mathrm{~N}_{2} \mathrm{O}_{4} 307.2$; found 321.2.

Dimethyl-carbamic acid 2-acetyl-5-(1-diethylamino-ethyl)phenyl ester ( $w 7)$ : Compound w7 was obtained from compound $7 \mathrm{c}$ and dimethylcarbamoyl chloride by general procedure $\mathrm{D}$; yield $88.6 \%$. ${ }^{1} \mathrm{H}$ NMR $\left(400 \mathrm{MHz}, \mathrm{CDCl}_{3}\right): \delta 7.73(1 \mathrm{H}, \mathrm{d}, \mathrm{J}=8.0 \mathrm{~Hz}), 7.30(1 \mathrm{H}, \mathrm{dd}$, $\left.\mathrm{J}_{1}=8.0 \mathrm{~Hz}, \mathrm{~J}_{2}=1.2 \mathrm{~Hz}\right), 7.16(1 \mathrm{H}, \mathrm{d}, \mathrm{J}=1.2 \mathrm{~Hz}), 3.82(1 \mathrm{H}, \mathrm{q}, \mathrm{J}=6.8 \mathrm{~Hz})$, $3.15(3 \mathrm{H}, \mathrm{s}), 3.03(3 \mathrm{H}, \mathrm{s}), 2.55(3 \mathrm{H}, \mathrm{s}), 2.52(4 \mathrm{H}, \mathrm{m}), 1.32(3 \mathrm{H}, \mathrm{d}, \mathrm{J}=6.8$ $\mathrm{Hz}), 0.99(6 \mathrm{H}, \mathrm{t}, \mathrm{J}=6.8 \mathrm{~Hz})$. MS $\left([\mathrm{M}+\mathrm{H}]^{+}\right) \mathrm{m} / \mathrm{z}$ calcd for $\mathrm{C}_{17} \mathrm{H}_{26} \mathrm{~N}_{2} \mathrm{O}_{3}$ 307.2; found 307.2.

Ethyl-methyl-carbamic acid 2-acetyl-5-(1-diethylamino-ethyl)phenyl ester (w8): Compound w8 was obtained from compound $7 \mathrm{c}$ and $\mathrm{N}$-ethyl-N-methylcarbamoyl chloride by general procedure $\mathrm{D}$; yield $88.7 \%$. ${ }^{1} \mathrm{H}$ NMR $\left(400 \mathrm{MHz}, \mathrm{CDCl}_{3}\right): \delta 7.72(1 \mathrm{H}, \mathrm{d}, \mathrm{J}=8.0 \mathrm{~Hz})$, $7.29\left(1 \mathrm{H}, \mathrm{dd}, \mathrm{J}_{1}=8.0 \mathrm{~Hz}, \mathrm{~J}_{2}=1.2 \mathrm{~Hz}\right), 7.15(1 \mathrm{H}, \mathrm{d}, \mathrm{J}=8.0 \mathrm{~Hz}), 3.81(1 \mathrm{H}, \mathrm{q}$, $\mathrm{J}=6.4 \mathrm{~Hz}), 3.53\left(\mathrm{q}, 1 \mathrm{H}, \mathrm{J}=6.8 \mathrm{~Hz},-\mathrm{CONCH}_{2} \mathrm{CH}_{3}\right), 3.42(\mathrm{q}, 1 \mathrm{H}, \mathrm{J}=6.8 \mathrm{~Hz}$, $\left.-\mathrm{CONCH}_{2} \mathrm{CH}_{3}\right), 3.12(\mathrm{~s}, 1.5 \mathrm{H}), 3.00(1.5 \mathrm{H}, \mathrm{s}), 2.55(3 \mathrm{H}, \mathrm{s}), 2.53(4 \mathrm{H}$, m), $1.32(3 \mathrm{H}, \mathrm{d}, \mathrm{J}=6.8 \mathrm{~Hz}), 1.19(3 \mathrm{H}, \mathrm{m}), 0.99(6 \mathrm{H}, \mathrm{t}, \mathrm{J}=6.8 \mathrm{~Hz}) . \mathrm{MS}$ $\left([\mathrm{M}+\mathrm{H}]^{+}\right) \mathrm{m} / \mathrm{z}$ calcd for $\mathrm{C}_{18} \mathrm{H}_{28} \mathrm{~N}_{2} \mathrm{O}_{3} 321.2$; found 321.2.
Diethyl-carbamic acid 2-acetyl-5-(1-diethylamino-ethyl)-phenyl ester ( $w 9)$ : $\mathrm{w} 9$ was obtained from compound $7 \mathrm{c}$ and diethylcarbamyl chloride by general procedure D; yield $89.3 \% .{ }^{1} \mathrm{H}$ NMR $(400 \mathrm{MHz}$, $\left.\mathrm{CDCl}_{3}\right): \delta 7.71\left(1 \mathrm{H}, \mathrm{dd}, \mathrm{J}_{1}=8.0 \mathrm{~Hz}, \mathrm{~J}_{2}=2.4 \mathrm{~Hz}\right), 7.28\left(1 \mathrm{H}, \mathrm{dd}, \mathrm{J}_{1}=8.0 \mathrm{~Hz}\right.$, $\left.\mathrm{J}_{2}=1.6 \mathrm{~Hz}\right), 7.13(1 \mathrm{H}, \mathrm{d}, \mathrm{J}=1.2 \mathrm{~Hz}), 3.81(1 \mathrm{H}, \mathrm{m}), 3.49(2 \mathrm{H}, \mathrm{m}), 3.38(2 \mathrm{H}$, $\mathrm{m}), 2.54(3 \mathrm{H}, \mathrm{s}), 2.52(4 \mathrm{H}, \mathrm{m}), 1.30(6 \mathrm{H}, \mathrm{m}), 1.21(3 \mathrm{H}, \mathrm{m}), 0.98(6 \mathrm{H}$, $\mathrm{m}$,$) . MS \left([\mathrm{M}+\mathrm{H}]^{+}\right) \mathrm{m} / \mathrm{z}$ calcd for $\mathrm{C}_{19} \mathrm{H}_{30} \mathrm{~N}_{2} \mathrm{O}_{3} 335.2$; found 335.2.

Pyrrolidine-1-carboxylic acid 2-acetyl-5-(1-diethylamino-ethyl)phenyl ester (w10): Compound w10 was obtained from compound $7 \mathrm{c}$ and 1-pyrrolidinecarbonyl chloride by general procedure $\mathrm{D}$; yield 87.5\%. ${ }^{1} \mathrm{H}$ NMR $\left(400 \mathrm{MHz}, \mathrm{CDCl}_{3}\right): \delta 7.73(1 \mathrm{H}, \mathrm{d}, \mathrm{J}=8.0 \mathrm{~Hz}), 7.29(1 \mathrm{H}$, dd, $\left.J_{1}=8.0 \mathrm{~Hz}, \mathrm{~J}_{2}=1.6 \mathrm{~Hz}\right), 7.14(1 \mathrm{H}, \mathrm{d}, \mathrm{J}=1.2 \mathrm{~Hz}), 3.81(1 \mathrm{H}, \mathrm{q}, \mathrm{J}=6.8 \mathrm{~Hz})$, $3.62(2 \mathrm{H}, \mathrm{t}, \mathrm{J}=6.8 \mathrm{~Hz}), 3,49(2 \mathrm{H}, \mathrm{t}, \mathrm{J}=6.8 \mathrm{~Hz}), 2.55(3 \mathrm{H}, \mathrm{s}), 2.53(4 \mathrm{H}$, m), $1.97(4 \mathrm{H}, \mathrm{m}), 1.31(3 \mathrm{H}, \mathrm{d}, \mathrm{J}=6.4 \mathrm{~Hz}), 0.99(6 \mathrm{H}, \mathrm{t}, \mathrm{J}=7.2 \mathrm{~Hz}) . \mathrm{MS}$ $\left([\mathrm{M}+\mathrm{H}]^{+}\right) \mathrm{m} / \mathrm{z}$ calcd for $\mathrm{C}_{19} \mathrm{H}_{28} \mathrm{~N}_{2} \mathrm{O}_{3} 335.2$; found 335.2.

4-Methyl-piperazine-1-carboxylic acid 2-acetyl-5-(1diethylaminoethyl)-phenyl ester (w11): Compound w11 was obtained from compound $7 \mathrm{c}$ and 4-Methyl-piperazine-1-carbonyl chloride by general procedure $\mathrm{D}$; yield $80.2 \%$. ${ }^{1} \mathrm{H}$ NMR $\left(400 \mathrm{MHz}, \mathrm{CDCl}_{3}\right): \delta 7.73$ $(1 \mathrm{H}, \mathrm{d}, \mathrm{J}=8.0 \mathrm{~Hz}), 7.32(1 \mathrm{H}, \mathrm{d}, \mathrm{J}=8.0 \mathrm{~Hz}), 7.16(1 \mathrm{H}, \mathrm{s}), 3.82(1 \mathrm{H}, \mathrm{q}, \mathrm{J}=6.8$ $\mathrm{Hz}), 3.74(2 \mathrm{H}, \mathrm{m}), 3.60(2 \mathrm{H}, \mathrm{m}), 2,54(3 \mathrm{H}, \mathrm{s}), 2.50(8 \mathrm{H}, \mathrm{m}), 2.36(\mathrm{~s}, 3 \mathrm{H}$, $\left.-\mathrm{NCH}_{3}\right), 1.32(3 \mathrm{H}, \mathrm{d}, \mathrm{J}=6.8 \mathrm{~Hz}), 0.99(6 \mathrm{H}, \mathrm{t}, \mathrm{J}=7.2 \mathrm{~Hz}$,$) . MS \left([\mathrm{M}+\mathrm{H}]^{+}\right)$ $\mathrm{m} / \mathrm{z}$ calcd for $\mathrm{C}_{20} \mathrm{H}_{31} \mathrm{~N}_{3} \mathrm{O}_{3} 362.2$; found 362.2.

Morpholine-4-carboxylic acid 2-acetyl-5-(1-diethylamino-ethyl)phenyl ester (w12): Compound w12 was obtained from compound $7 \mathrm{c}$ and morpholine-4-carbonyl chloride by general procedure $\mathrm{D}$; yield 90.2\%. ${ }^{1} \mathrm{H}$ NMR $\left(400 \mathrm{MHz}, \mathrm{CDCl}_{3}\right): \delta 7.74(1 \mathrm{H}, \mathrm{d}, \mathrm{J}=8.0 \mathrm{~Hz}), 7.32(1 \mathrm{H}$, dd, $\left.J_{1}=8.0 \mathrm{~Hz}, \mathrm{~J}_{2}=1.2 \mathrm{~Hz}\right), 7.17(1 \mathrm{H}, \mathrm{d}, \mathrm{J}=1.6 \mathrm{~Hz}), 3.78(4 \mathrm{H}, \mathrm{m}), 3.83$ $(1 \mathrm{H}, \mathrm{m}), 3.72(2 \mathrm{H}, \mathrm{m}), 3.60(2 \mathrm{H}, \mathrm{m}), 2.54(3 \mathrm{H}, \mathrm{s}), 2.52(4 \mathrm{H}, \mathrm{m}), 1.32$ $(3 \mathrm{H}, \mathrm{d}, \mathrm{J}=6.4 \mathrm{~Hz}), 0.99(6 \mathrm{H}, \mathrm{t}, \mathrm{J}=7.2 \mathrm{~Hz}) . \mathrm{MS}\left([\mathrm{M}+\mathrm{H}]^{+}\right) \mathrm{m} / \mathrm{z}$ calcd for $\mathrm{C}_{19} \mathrm{H}_{28} \mathrm{~N}_{2} \mathrm{O}_{4} 349.2$; found 349.2.

Dimethyl-carbamic acid 2-acetyl-5-(1-morpholin-4-yl-ethyl)phenyl ester (w13): Compound w13 was obtained from compound 7f and dimethylcarbamoyl chloride by general procedure D; yield 90.4\%. ${ }^{1} \mathrm{H}$ NMR $\left(400 \mathrm{MHz}, \mathrm{CDCl}_{3}\right): \delta 7.73(1 \mathrm{H}, \mathrm{d}, \mathrm{J}=8.0 \mathrm{~Hz}), 7.25(1 \mathrm{H}$, dd, $\left.J_{1}=8.0 \mathrm{~Hz}, \mathrm{~J}_{2}=1.6 \mathrm{~Hz}\right), 7.12(1 \mathrm{H}, \mathrm{d}, \mathrm{J}=2.0 \mathrm{~Hz}), 3.69(4 \mathrm{H}, \mathrm{m}), 3.33$ $(1 \mathrm{H}, \mathrm{q}, \mathrm{J}=6.8 \mathrm{~Hz}), 3.15(3 \mathrm{H}, \mathrm{s}), 3.03(3 \mathrm{H}, \mathrm{s}), 2.54(3 \mathrm{H}, \mathrm{s}), 2.49(2 \mathrm{H}$, m), $2.37(2 \mathrm{H}, \mathrm{m}), 1.33(3 \mathrm{H}, \mathrm{d}, \mathrm{J}=6.8 \mathrm{~Hz}$,$) . MS \left([\mathrm{M}+\mathrm{H}]^{+}\right) \mathrm{m} / \mathrm{z}$ calcd for $\mathrm{C}_{17} \mathrm{H}_{24} \mathrm{~N}_{2} \mathrm{O}_{4} 3321.2$; found 321.2.

Ethyl-methyl-carbamic acid 2-acetyl-5-(1-morpholin-4-yl-ethyl)phenyl ester (w14): Compound w14 was obtained from compound 7f and N-ethyl-N-methylcarbamoyl chloride by general procedure $\mathrm{D}$; yield $89.9 \% .{ }^{1} \mathrm{H} \mathrm{NMR}\left(400 \mathrm{MHz}, \mathrm{CDCl}_{3}\right): \delta 7.72(1 \mathrm{H}, \mathrm{d}, \mathrm{J}=8.0 \mathrm{~Hz})$, $7.25(1 \mathrm{H}, \mathrm{d}, \mathrm{J}=8.0 \mathrm{~Hz}), 7.11(1 \mathrm{H}, \mathrm{d}, \mathrm{J}=10.0 \mathrm{~Hz}), 3.69(4 \mathrm{H}, \mathrm{m}), 3.53(1 \mathrm{H}$, q, J=7.2 Hz), $3.41(1 \mathrm{H}, \mathrm{q}, \mathrm{J}=7.2 \mathrm{~Hz}), 3.33(1 \mathrm{H}, \mathrm{q}), 3.12(1.5 \mathrm{H}, \mathrm{s}), 3.00$ $(1.5 \mathrm{H}, \mathrm{s}), 2.54(3 \mathrm{H}, \mathrm{s}), 2.49(2 \mathrm{H}, \mathrm{m}), 2.38(2 \mathrm{H}, \mathrm{m}), 1.33(3 \mathrm{H}, \mathrm{d}, \mathrm{J}=6.4$ $\mathrm{Hz}), 1.27(1.5 \mathrm{H}, \mathrm{t}, \mathrm{J}=7.2 \mathrm{~Hz}), 1.21(1.5 \mathrm{H}, \mathrm{t}, \mathrm{J}=7.2 \mathrm{~Hz}) . \mathrm{MS}\left([\mathrm{M}+\mathrm{H}]^{+}\right) \mathrm{m} / \mathrm{z}$ calcd for $\mathrm{C}_{18} \mathrm{H}_{26} \mathrm{~N}_{2} \mathrm{O}_{4}$ 3321.2; found 335.2.

Diethyl-carbamic acid 2-acetyl-5-(1-morpholin-4-yl-ethyl)phenyl ester (w15): Compound w15 was obtained from compound $7 \mathrm{f}$ and diethylcarbamyl chloride by general procedure $\mathrm{D}$; yield $91.2 \% .{ }^{1} \mathrm{H}$ NMR $\left(400 \mathrm{MHz}, \mathrm{CDCl}_{3}\right): \delta 7.63(1 \mathrm{H}, \mathrm{d}, \mathrm{J}=8.0 \mathrm{~Hz}), 7.18(1 \mathrm{H}, \mathrm{d}, \mathrm{J}=8.0$ $\mathrm{Hz}), 7.02(1 \mathrm{H}, \mathrm{s}), 3.47(4 \mathrm{H}, \mathrm{m}), 3.40(2 \mathrm{H}, \mathrm{q}, \mathrm{J}=7.2 \mathrm{~Hz}), 3.23(3 \mathrm{H}, \mathrm{m})$, $2.35(5 \mathrm{H}, \mathrm{m}), 2.22(2 \mathrm{H}, \mathrm{m}), 1.19(3 \mathrm{H}, \mathrm{d}, \mathrm{J}=6.8 \mathrm{~Hz}), 1.16(3 \mathrm{H}, \mathrm{t}, \mathrm{J}=7.2$ $\mathrm{Hz}), 1.03(3 \mathrm{H}, \mathrm{t}, \mathrm{J}=6.8 \mathrm{~Hz}$,$) . MS \left([\mathrm{M}+\mathrm{H}]^{+}\right) \mathrm{m} / \mathrm{z}$ calcd for $\mathrm{C}_{19} \mathrm{H}_{28} \mathrm{~N}_{2} \mathrm{O}_{4}$ 349.2; found 349.2 .

Pyrrolidine-1-carboxylic acid 2-acetyl-5-(1-morpholin-4yl-ethyl)-phenyl ester (w16): Compound w16 was obtained from compound $\mathbf{7 f}$ and 1-pyrrolidinecarbonyl chloride by general procedure 
D; yield $91.2 \%$; yield $87.5 \% .{ }^{1} \mathrm{H}$ NMR $\left(400 \mathrm{MHz} \mathrm{CDCl}_{3}\right): \delta 7.66(1 \mathrm{H}, \mathrm{d}$, $\mathrm{J}=8.0 \mathrm{~Hz}), 7.18(1 \mathrm{H}, \mathrm{d}, \mathrm{J}=8.0 \mathrm{~Hz}), 7.08(1 \mathrm{H}, \mathrm{s}), 3.62(4 \mathrm{H}, \mathrm{m}), 3.55(2 \mathrm{H}$, $\mathrm{t}, \mathrm{J}=6.4 \mathrm{~Hz}), 3.42(2 \mathrm{H}, \mathrm{t}, \mathrm{J}=6.4 \mathrm{~Hz}), 3.22(1 \mathrm{H}, \mathrm{m}), 2.48(3 \mathrm{H}, \mathrm{s}), 2.42(2 \mathrm{H}$, m), $2.36(2 \mathrm{H}, \mathrm{m}), 1.90(4 \mathrm{H}, \mathrm{m}), 1.26(3 \mathrm{H}, \mathrm{d}, \mathrm{J}=6.0 \mathrm{~Hz},) . \mathrm{MS}\left([\mathrm{M}+\mathrm{H}]^{+}\right)$ $\mathrm{m} / \mathrm{z}$ calcd for $\mathrm{C}_{19} \mathrm{H}_{26} \mathrm{~N}_{2} \mathrm{O}_{4} 347.2$; found 347.2.

Piperidine-1-carboxylic acid 2-acetyl-5-(1-morpholin-4-ylethyl)-phenyl ester (w17): Compound w17 was obtained from compound $\mathbf{7 f}$ and piperidine-1-carbonyl chloride by general procedure D; yield 88.6\%. ${ }^{1} \mathrm{H}$ NMR $\left(400 \mathrm{MHz}, \mathrm{CDCl}_{3}\right): \delta 7.73(1 \mathrm{H}, \mathrm{d}, \mathrm{J}=8.0 \mathrm{~Hz})$, $7.25(1 \mathrm{H}, \mathrm{d}, \mathrm{J}=8.0 \mathrm{~Hz}), 7.11(1 \mathrm{H}, \mathrm{s}), 3.69(4 \mathrm{H}, \mathrm{m}), 3.66(2 \mathrm{H}, \mathrm{m}), 3.52$ $(2 \mathrm{H}, \mathrm{m}), 3.33(1 \mathrm{H}, \mathrm{q}, \mathrm{J}=6.4 \mathrm{~Hz}), 2.54(3 \mathrm{H}, \mathrm{s}), 2.49(2 \mathrm{H}, \mathrm{m}), 2.39(2 \mathrm{H}$, $\mathrm{m}), 1.68(6 \mathrm{H}, \mathrm{m}), 1.33(3 \mathrm{H}, \mathrm{d}, \mathrm{J}=6.4 \mathrm{~Hz})$. MS $\left([\mathrm{M}+\mathrm{H}]^{+}\right) \mathrm{m} / \mathrm{z}$ calcd for $\mathrm{C}_{20} \mathrm{H}_{28} \mathrm{~N}_{2} \mathrm{O}_{4} 360.4$; found 360.4.

Morpholine-4-carboxylic acid 2-acetyl-5-(1-morpholin-4yl-ethyl)-phenyl ester (w18): Compound w18 was obtained from compound $\mathbf{7 f}$ and morpholine-4-carbonyl chloride by general procedure D; yield 90.0\%. ${ }^{1} \mathrm{H}$ NMR $\left(400 \mathrm{MHz}, \mathrm{CDCl}_{3}\right): \delta 7.75(1 \mathrm{H}$, d, J=8.0 Hz), $7.27(1 \mathrm{H}, \mathrm{d}, \mathrm{J}=8.0 \mathrm{~Hz}), 7.14(1 \mathrm{H}, \mathrm{s}), 3.79(4 \mathrm{H}, \mathrm{m}), 3.69$ $(6 \mathrm{H}, \mathrm{m}), 3.58(2 \mathrm{H}, \mathrm{m}), 3.35(1 \mathrm{H}, \mathrm{q}, \mathrm{J}=6.4 \mathrm{~Hz}), 2.55(3 \mathrm{H}, \mathrm{s}), 2.49(2 \mathrm{H}$, $\mathrm{m}), 2.38(2 \mathrm{H}, \mathrm{m}), 1.34(3 \mathrm{H}, \mathrm{d}, \mathrm{J}=6.4 \mathrm{~Hz})$. MS $\left([\mathrm{M}+\mathrm{H}]^{+}\right) \mathrm{m} / \mathrm{z}$ calcd for $\mathrm{C}_{19} \mathrm{H}_{26} \mathrm{~N}_{2} \mathrm{O}_{5}$ 363.2; found 363.2.

Ethyl-methyl-carbamic acid 2-acetyl-5-[1-(ethyl-methyl-amino)ethyl]-phenyl ester (w19): Compound w19 was obtained from compound $\mathbf{7 b}$ and $\mathrm{N}$-ethyl-N-methylcarbamoyl chloride by general procedure 4.7 .1 ; yield $91.6 \% .{ }^{1} \mathrm{H}$ NMR $\left(400 \mathrm{MHz}, \mathrm{CDCl}_{3}\right): \delta 7.73(1 \mathrm{H}$, $\mathrm{d}, \mathrm{J}=8.0 \mathrm{~Hz}), 7.24\left(1 \mathrm{H}, \mathrm{dd}, \mathrm{J}_{1}=8.0 \mathrm{~Hz}, \mathrm{~J}_{2}=1.6 \mathrm{~Hz}\right), 7.11(1 \mathrm{H}, \mathrm{d}, \mathrm{J}=8.0$ $\mathrm{Hz}), 3.54(2 \mathrm{H}, \mathrm{m}), 3.41(1 \mathrm{H}, \mathrm{q}, \mathrm{J}=6.8 \mathrm{~Hz}),, 3.11(1.5 \mathrm{H}, \mathrm{s}), 3.00(1.5 \mathrm{H}$, s), $2.54(3 \mathrm{H}, \mathrm{s}), 2.49(1 \mathrm{H}, \mathrm{m}), 2.36(1 \mathrm{H}, \mathrm{m}), 2.19(3 \mathrm{H}, \mathrm{s}), 1.33(3 \mathrm{H}, \mathrm{d}$, $\mathrm{J}=6.8 \mathrm{~Hz}), 1.28(1.5 \mathrm{H}, \mathrm{t}, \mathrm{J}=6.8 \mathrm{~Hz}), 1.20(1.5 \mathrm{H}, \mathrm{t}, \mathrm{b}, \mathrm{J}=6.8 \mathrm{~Hz}), 1.02$ $(3 \mathrm{H}, \mathrm{t}, \mathrm{J}=6.8 \mathrm{~Hz}$,$) . MS \left([\mathrm{M}+\mathrm{H}]^{+}\right) \mathrm{m} / \mathrm{z}$ calcd for $\mathrm{C}_{17} \mathrm{H}_{26} \mathrm{~N}_{2} \mathrm{O}_{3} 307.2$; found 307.2.

Ethyl-methyl-carbamic acid 2-acetyl-5-(1-pyrrolidin-1-yl-ethyl)phenyl ester (w20): Compound w20 was obtained from compound 7d and N-ethyl-N-methylcarbamoyl chloride by general procedure D; yield $87.7 \% .{ }^{1} \mathrm{H}$ NMR $\left(400 \mathrm{MHz}, \mathrm{CDCl}_{3}\right): \delta 7.72(1 \mathrm{H}, \mathrm{d}, \mathrm{J}=8.0 \mathrm{~Hz}), 7.25$ $\left(1 \mathrm{H}, \mathrm{dd}, \mathrm{J}_{1}=8.0 \mathrm{~Hz}, \mathrm{~J}_{2}=1.2 \mathrm{~Hz}\right), 7.13(1 \mathrm{H}, \mathrm{d}, \mathrm{J}=6.8 \mathrm{~Hz}), 3.52(1 \mathrm{H}, \mathrm{q}, \mathrm{J}=6.8$ $\mathrm{Hz}), 3.41(1 \mathrm{H}, \mathrm{q}, \mathrm{J}=6.8 \mathrm{~Hz}), 3.22(1 \mathrm{H}, \mathrm{q}, \mathrm{J}=6.8 \mathrm{~Hz}), 3.11(1.5 \mathrm{H}, \mathrm{s}), 3.00$ $(1.5 \mathrm{H}, \mathrm{s}), 2.54(3 \mathrm{H}, \mathrm{s}), 2.49(2 \mathrm{H}, \mathrm{m}), 2.39(2 \mathrm{H}, \mathrm{m}), 1.78(4 \mathrm{H}, \mathrm{m}), 1.38$ $(3 \mathrm{H}, \mathrm{d}, \mathrm{J}=6.8 \mathrm{~Hz}), 1.28(1.5 \mathrm{H}, \mathrm{m}), 1.20(1.5 \mathrm{H}, \mathrm{m}) . \mathrm{MS}\left([\mathrm{M}+\mathrm{H}]^{+}\right) \mathrm{m} / \mathrm{z}$ calcd for $\mathrm{C}_{18} \mathrm{H}_{26} \mathrm{~N}_{2} \mathrm{O}_{3}$; found 319.2.

Ethyl-methyl-carbamic acid 2-acetyl-5-(1-piperidin-1-yl-ethyl)phenyl ester (w21): Compound w21 was obtained from compound 7e and N-ethyl-N-methylcarbamoyl chloride by general procedure D; yield $86.9 \% .{ }^{1} \mathrm{H}$ NMR $\left(400 \mathrm{MHz}, \mathrm{CDCl}_{3}\right): \delta 7.72(\mathrm{~d}, 1 \mathrm{H}, \mathrm{J}=8.0 \mathrm{~Hz}, \mathrm{ArH})$, $7.24(\mathrm{~d}, 1 \mathrm{H}, \mathrm{J}=8.0 \mathrm{~Hz}, \mathrm{ArH}), 7.09$ (d, 1H, J=8.4 Hz, ArH), $3.52(\mathrm{~m}, 3 \mathrm{H}$, $\left.-\mathrm{CHCH}_{3},-\mathrm{CH}_{2} \mathrm{CH}_{3}\right), 3.43\left(\mathrm{~m}, 3 \mathrm{H},-\mathrm{NCH}_{3}\right), 2.54\left(\mathrm{~s}, 3 \mathrm{H},-\mathrm{COCH}_{3}\right), 2.37$ ( $\mathrm{m}, 4 \mathrm{H}$, piperidine), $1.54(\mathrm{~m}, 4 \mathrm{H}$, piperidine $), 1.40(\mathrm{~m}, 2 \mathrm{H}$, piperidine), $1.34\left(\mathrm{~d}, 3 \mathrm{H}, \mathrm{J}=6.8 \mathrm{~Hz},-\mathrm{CHCH}_{3}\right), 1.20\left(\mathrm{~m}, 3 \mathrm{H},-\mathrm{CH}_{2} \mathrm{CH}_{3}\right)$. MS $\left([\mathrm{M}+\mathrm{H}]^{+}\right)$ $\mathrm{m} / \mathrm{z}$ calcd for $\mathrm{C}_{19} \mathrm{H}_{28} \mathrm{~N}_{2} \mathrm{O}_{3}$; found 332.2 .

Ethyl-methyl-carbamic acid 2-acetyl-5-[1-(4-methyl-piperazin1-yl)-ethyl]-phenyl ester (w22): Compound w22 was obtained from compound $7 \mathbf{g}$ and $\mathrm{N}$-ethyl-N-methylcarbamoyl chloride by general procedure 4.7.1; yield 85.3\%. ${ }^{1} \mathrm{H}$ NMR $\left(400 \mathrm{MHz}, \mathrm{CDCl}_{3}\right): \delta 7.71(1 \mathrm{H}$, d, J=8.0 Hz), $7.24(1 \mathrm{H}, \mathrm{d}, \mathrm{J}=8.0 \mathrm{~Hz}), 7.10(1 \mathrm{H}, \mathrm{d}, \mathrm{J}=9.2 \mathrm{~Hz}), 3.52(1 \mathrm{H}$, $\mathrm{m}), 3.39(2 \mathrm{H}, \mathrm{m}), 3.11(1.5 \mathrm{H}, \mathrm{s}), 3.00(1.5 \mathrm{H}, \mathrm{s}), 2.53(3 \mathrm{H}, \mathrm{d}, \mathrm{J}=2.0 \mathrm{~Hz})$, $2.47(8 \mathrm{H}, \mathrm{m}), 2.32(3 \mathrm{H}, \mathrm{d}, \mathrm{J}=2.0 \mathrm{~Hz}), 1.33\left(3 \mathrm{H}, \mathrm{dd}, \mathrm{J}_{1}=6.4 \mathrm{~Hz}, \mathrm{~J}_{2}=2.8 \mathrm{~Hz}\right)$, $1.291 .5 \mathrm{H},(\mathrm{m}), 1.20(1.5 \mathrm{H}, \mathrm{m}) . \mathrm{MS}\left([\mathrm{M}+\mathrm{H}]^{+}\right) \mathrm{m} / \mathrm{z}$ calcd for $\mathrm{C}_{19} \mathrm{H}_{29} \mathrm{~N}_{3} \mathrm{O}_{3}$; found 348.2 .

\section{Spectrophotometric measurement of complex with $\mathrm{Cu}^{2+}$ and} $\mathrm{Fe}^{2+}$

All compounds were tested as metal chelators, using difference UVVis spectra recorded in methanol at $298 \mathrm{~K}$ with wavelength ranging from $210 \mathrm{~nm}$ to $400 \mathrm{~nm}$. Numerical subtraction of the spectra of the metal alone and the compound alone from the spectra of the mixture obtained the difference UV-Vis spectra due to complex formation. A fixed amount of 9 f $\left(25 \mu \mathrm{mol} \cdot \mathrm{L}^{-1}\right)$ was mixed with growing amounts of copper ion $\left(1.25 \mu \mathrm{mol} \cdot \mathrm{L}^{-1}\right.$ to $\left.50 \mu \mathrm{mol} \cdot \mathrm{L}^{-1}\right)$ and tested the difference UVVis spectra to investigate the ratio of ligand/metal in the complex.

\section{Study of AChE hydrolysis}

Compound w13 $20 \mu \mathrm{L}\left(3 \mathrm{~mol} \cdot \mathrm{L}^{-1}\right)$ was added into PBS buffer $(\mathrm{pH}$ 7.4) $160 \mu \mathrm{L}, 0.05 \%(\mathrm{v} / \mathrm{v})$ Triton X-100 $10 \mu \mathrm{L}$ and rat AChE homogenate, was incubated at $37^{\circ} \mathrm{C}$. After $0.1 \mathrm{~h}, 0.5 \mathrm{~h}, 1 \mathrm{~h}, 3 \mathrm{~h}$, and $6 \mathrm{~h}, 20 \mu \mathrm{L}$ was taken out from the incubating mixture with a pipette gun, extracted with ethyl acetate, combined with organic layer, dried by anhydrous sodium sulfate and evaporated solvent. The residue was dissolved in acetonitrile and analyzed with HPLC. HPLC analyses was conducted on Dikma Techndogies C18 (symmetry: $250 \mathrm{~mm} \times 4.6 \mu \mathrm{m}$ ) column at $35^{\circ} \mathrm{C}$, eluent: acetonitrile: $0.1 \%$ ethylamine aqueous solution $=6: 4$, flow rate: $1 \mathrm{~mL} / \mathrm{min}$. detection at $254 \mathrm{~nm}$.

\section{Conflict of Interest}

The authors declare no competing financial interest.

\section{Acknowledgments}

This work was supported by Natural Science Foundation of China (2015F50015), Natural Science Foundation of Zhejiang Province (LY17H310008, LQ17H300003), Health and Family Planning Commission of Zhejiang Province (XKQ-010-001 and 2017143412), and the State Key Laboratory of Medicinal Chemical Biology.

\section{References}

1. Latta CH, Brothers HM, Wilcock DM (2014) Neuroin-flammation in Alzheimer $s$ disease: A source of heterogeneity and target for personalized therapy. Neuroscience 5: S0306-S4522.

2. Behl C (2006) The search for novel avenues for the therapy and prevention of Alzheimer's disease. Drug News Perspect 19: 5-12.

3. Braak H, Feldengut S, Del Tredici K (2013) Pathogenese und Prävention des M. Alzheimer. Nervenarzt 84: 477-482.

4. Tiraboschi P, Hansen LA, Thal LJ, Corey-Bloom J (2004) The importance of neuritic plaques and tangles to the development and evolution of AD. Neurology 62: 1984-1989.

5. Morphy R, Rankovic Z (2005) Designed multiple ligands. An emerging drug discovery paradigm. J. Med. Chem. 48: 6523-6543.

6. Iqbal K, Grundke-Iqbal I (2010) Alzheimer's disease, a multifactorial disorder seeking multithera- pies. Alzheimers Dement 6: 420-424.

7. Bolognesi ML, Matera R, Minarini A, Rosini M, Melchiorre C (2009) Alzheimer's disease: new approaches to drug discovery. Curr. Opin. Chem. Biol 13: 303-308.

8. Camps $P$, Munoz-Torrero D (2002) Cholinergic drugs in pharmacotherapy of Alzheimer's disease. Mini-Rev Med Chem 2: 11-25.

9. Corey-Bloom J, Anand R, Veach J (1998) A randomized trial evaluating the efficacy and safety of ENA 713 (rivastigmine tartrate), a new acetylcholinesterase inhibitor, in patients with mild to moderately severe Alzheimer's disease. Int. J. Geriatr Psychopharmacol 1: 55-65.

10. Zatta P, Drago D, Bolognin S, Sensi SL (2009) Alzheimer's disease, metal ions and metal homeostatic therapy. Trends Pharmaco Sci 30: 346-355.

11. Lovell MA, Robertson JD, Teesdale WJ, Campbell JL, Markesbery WR (1998) Copper, iron and zinc in Alzheimer's disease senile plaques. J Neurol Sci 158: 47-52.

12. Yona RL, Mazères $S$, Faller $P$, Gras $E$ (2008) Thioflavin derivatives as markers for amyloid- $\beta$ fibrils: insights into structural features important for high-affinity binding. Chem. Med. Chem 3: 63-66. 
Citation: Liang M, Huang W, Wang B, Wei W, Zhang C, et al. (2017) Design, Synthesis and Biological Evaluation of 1-Phenyl-Ethanone Derivatives for Multi-Targeted Treatment of Alzheimer's Disease. Med Chem 7: 285-293. doi: 10.4172/2161-0444.1000469

13. Amir A, Shmuel E, Zagalsky R, Sayer AH, Nadel Y, et al. (2012) Nucleoside5'-phosphorothioate analogues are biocompatible antioxidants dissolving efficiently amyloid beta-metal ion aggregate. Dalton Trans 14: 8539-8549.

14. Nikolaev A, McLaughlin T, O'Leary D, Tessier-Lavigne M (2009) APP binds DR6 to cause axon pruning and neuron death via distinct caspases. Nature 457: 981-989.

15. Selkoe DJ (2002) Alzheimer's disease is a synaptic failure. Science 298: 789791.

16. Hardy J, Selkoe DJ (2002) The amyloid hypothesis of Alzheimer's disease: progress and problems on the road to therapeutics. Science 297: 353-356.

17. Barone E (2017) Oxidative stress and Alzheimer's Disease: Where do we stand? Curr. Alzheimer Res 13: 108-111.

18. Zatta P, Drago D, Bolognin S, Sensi SL (2009) Alzheimer's disease, metal ions and metal homeostatic therapy. Trends Pharmaco Sci 30: 346-355.

19. Smith DG, Ciccotosto GD, Tew DJ, Perez K, Curtain CC, et al. (2010) Histidine 14 modulates membrane binding and neurotoxicity of the Alzheimer's disease amyloid-beta peptide. J. Alzheimers Dis 19: 1387-1400

20. Inestrosa NC, Dinamarca MC, Alvarez A (2008) Amyloid-cholinesterase interactions. FEBS J 275: 625-632.

21. Bush Al (2008) Drug development based on the metals hypothesis of Alzheimer's disease. J. Alzheimer's Dis 15: 223-240.

22. Raffa DF, Gomez-Balderas R, Brunelle P, Rickard GA, Rauk A (2005) A $\beta$ initio model studies of copper binding to peptides containing a His-His sequence: relevance to the beta-amyloid peptide of Alzheimer's disease. J. Biol. Inorg. Chem 10: 8872-8902.

23. Faller $P$ (2012) Copper in Alzheimer disease: too much, too little, or misplaced? Free Radic. Bio. Med 52: 747-748.
24. Srinivas NR (2017) Transdermal Rivastigmine Delivery for Alzheimer Disease: Amenability of Exposure Predictions of Rivastigmine and Metabolite, NAP22690, by Linear Regression Model Using Limited Samples. Clin. Neuropharmacol 39: 169-177.

25. Inestrosa NC, Alvarez A, Dinamarca MC, Pérez-Acle T, Colombres M (2005) Acetylcholinesterase-amyloid- $\beta$-peptide interaction: effect of Congo Red and the role of the Wnt pathway. Curr. Alzheimer Res 2: 301-306.

26. Huang X, Cuanjungco MP, Atwood CS, Hartshorn MA, Tyndall JD, et al. (1999) $\mathrm{Cu}$ (II) potentiation of alzheimer abeta neurotoxicity. Correlation with cell-free hydrogen peroxide production and metal reduction. J Biol Chem 274: 37111 37116.

27. Huang W, Lv D, Yu H, Sheng R, Kim SC, Wu P, et al. (2010) Dual-targetdirected 1,3-diphenylurea derivatives: BACE 1 inhibitor and metal chelator against Alzheimer's disease. Bioorg Med Chem 18: 5610-5615.

28. Kelcnyi G (1967) On the histochemistry of azo group-free thiazole dyes. J. Histochem. Cytochem 15: 172-180.

29. Classics C, Ellman GL, Courtney KD, Andres V, Featherstone RM (1961) A new and rapid colorimetric determination of acetylcholinesterase activity. Biochem. Pharmacol 7: 88-95.

30. Khan I, Samad A, Khan AZ, Habtemariam S, Badshah A, et al. (2013) Molecular interactions of 4-acetoxy-plakinamine B with peripheral anionic and other catalytic subsites of the aromatic gorge of acetylcholinesterase: Computational and structural insights. Pharmaceutical Biology 6: 722-727.

31. Wenhai Huang, Li Tang, Ying Shi, Shufang Huang, Lei Xu, Rong Sheng, Peng $\mathrm{Wu}$, Jia Li, Naiming Zhou, Yongzhou Hu, Searching for the Multi-TargetDirected Ligands against Alzheimer's disease: Discovery of quinoxaline-based hybrid compounds with AChE, H3R and BACE 1 inhibitory activities. Bioorgan. Med. Chem., 2011, 19, 7158-7167. 